Article

\title{
Development and Techno-Economic Analysis of an Advanced Recycling Process for Photovoltaic Panels Enabling Polymer Separation and Recovery of Ag and Si
}

\author{
Antonio Rubino ${ }^{1}\left(\mathbb{D}\right.$, Giuseppe Granata $^{2}{ }^{\circledR}$, Emanuela Moscardini ${ }^{3}$, Ludovica Baldassari ${ }^{3}$, \\ Pietro Altimari ${ }^{1,3}$, Luigi Toro ${ }^{3}$ and Francesca Pagnanelli ${ }^{1,3, *(D)}$ \\ 1 Department of Chemistry, Sapienza University of Rome, P.le Aldo Moro 5, 00185 Rome, Italy; \\ antonio.rubino@uniroma1.it (A.R.); pietro.altimari@uniroma1.it (P.A.) \\ 2 Intelligen, Inc., 2326 Morse Avenue, Scotch Plains, NJ 07076, USA; ggranata@intelligen.com \\ 3 Eco Recycling Srl, Via di Vannina 88/94, 00156 Roma, Italy; emanuela.moscardini@ecorecycling.eu (E.M.); \\ ludovica.baldassari@ecorecycling.eu (L.B.); luigi.toro@ecorecycling.eu (L.T.) \\ * Correspondence: francesca.pagnanelli@uniroma1.it
}

Received: 12 September 2020; Accepted: 16 December 2020; Published: 18 December 2020

check for updates

\begin{abstract}
Photovoltaic panels were included in EU Directive as WEEE (Wastes of Electric and Electronic Equipment) requiring the implementation of dedicated collection schemes and end-of-life treatment ensuring targets in terms of recycling rate $(80 \%)$ and recovery rate $(85 \%)$. Photovoltaic panels are mainly made up of high-quality solar glass (70-90\%), but also metals are present in the frames (Al), the cell ( $\mathrm{Si}$ ), and metallic contacts ( $\mathrm{Cu}$ and $\mathrm{Ag}$ ). According to the panel composition, about $\$ 72$ per $100 \mathrm{~kg}$ of panels can be recovered by entirely recycling the panel metal content. The PhotoLife process for the treatment of end-of-life photovoltaic panels was demonstrated at pilot scale to recycle high value glass, $\mathrm{Al}$ and $\mathrm{Cu}$ scraps. A process upgrade is here reported allowing for polymer separation and Ag and Si recycling. By this advanced PhotoLife process, $82 \%$ recycling rate, $94 \%$ recovery rate, and $75 \%$ recoverable value were attained. Simulations demonstrated the economic feasibility of the process at processing capacity of 30,000 metric ton/y of end-of-life photovoltaic panels.
\end{abstract}

Keywords: end of life photovoltaic panels; polymers recycling; metals recycling; process simulation; SuperPro Designer

\section{Introduction}

One of the major challenges that humanity is facing is to promote the transition from traditional fossil fuels to long-term sustainable energies [1]. In recent decades, photovoltaic (PV) technology has become a competitive technological alternative allowing to reach appreciable power production by conversion of solar energy into electricity [2].

Si-crystalline photovoltaic panels (PVPs) currently represent the dominating technology [3] covering $90 \%$ of the global market share [4]. The application of alternative PV technologies, such as the thin-film Cd-Te and CIGS panels, is limited by the application of toxic metals ( $\mathrm{Cd}$ in $\mathrm{Cd}-\mathrm{Te}$ ) and rare elements (In and Ga in CIGS) [5], which contributes to consolidate the dominating market position of the Si based panels [3].

Taking into consideration the PVPs market growth recorded over the past decades [6], a progressively increasing annual flux of the end-of-life (EOL) PVPs is foreseen. Specifically, it is predicted that about 8 and 78 million EOL-PVPs tons could be generated within 2030 and 2050, respectively [7]. 
Recycling this huge flux of EOL-PVPs is indispensable to prevent that harmful elements contained in the panels, such as heavy metals, could be dispersed into the environment [8]. To this purpose, EU included EOL-PVPs in the class of the wastes of electric and electronic equipment (WEEE) [9], and established minimum targets for their collection (65\%), recycling $(80 \%)$, and recovery $(85 \%)$ starting from August 2018 (previous process targets were 70\% for recycling and $80 \%$ for recovery).

In addition to significant environmental benefits, the value of recycling also lies in the recovery of secondary raw materials [10]. Hence, in addition to the compliance with relevant regulations, the appropriate EOL-PVPs management may offer a further sustainable solution to raw materials supply. As a consequence, the EOL-PVPs treatment became an extensively studied topic, generally addressed through the life cycle analysis (LCA) methodology [11-16].

Considering that main recycling targets in a Si-crystalline PVP are glass, photovoltaic cells and metals, including panel frames (Al) and current collectors ( $\mathrm{Cu}$ and $\mathrm{Ag}$ ) [17], the following two observations should be taken into account: (i) the aluminum frame and front glass represent more than $80 \%$ of the PVP total weight and (ii) $80 \%$ of the overall PVP value is associated to the metals used in PV cell and electric contacts (mainly $\mathrm{Si}, \mathrm{Cu}$, and $\mathrm{Ag}$ ). This means that in order to guarantee the economic sustainability of the recycling process, metals of cell and contacts need to be recycled together with glass and frames (Figure 1). On the other hand, strategies focused solely on cell recovery cannot guarantee the minimum recycling targets set by regulations.
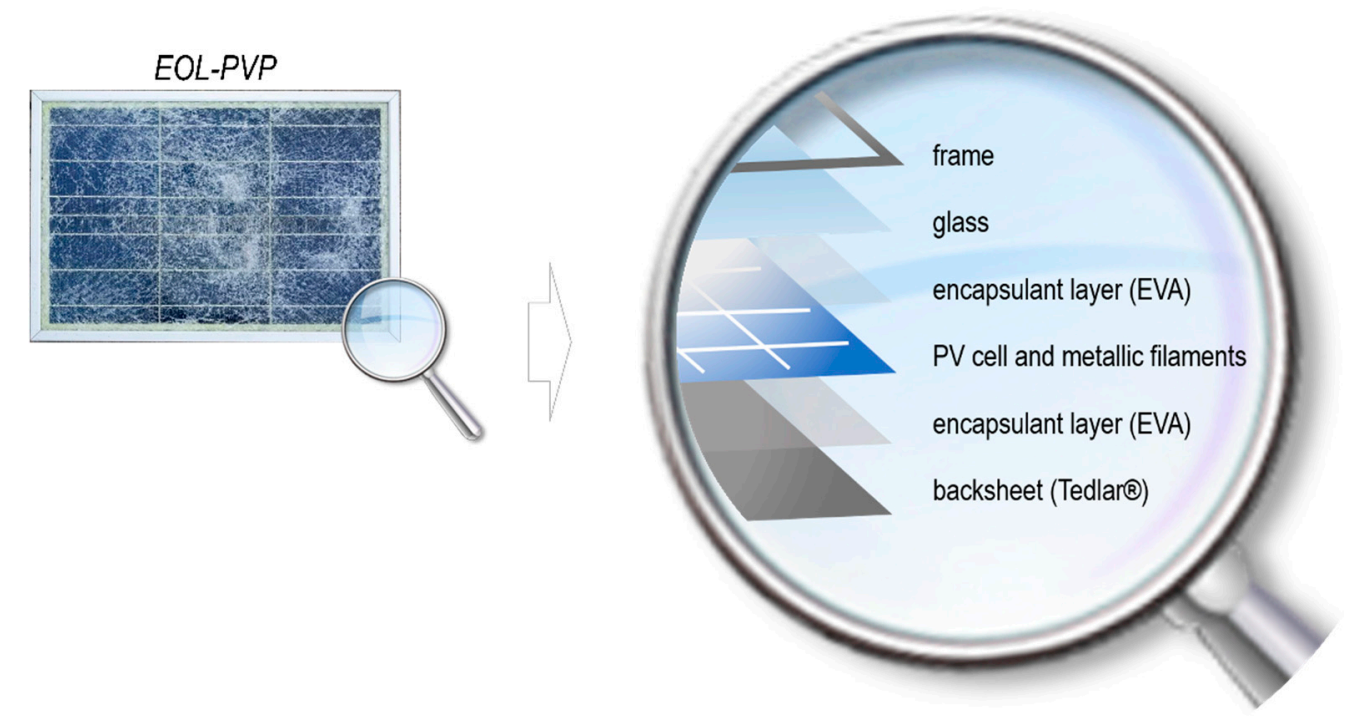

Figure 1. Exploded diagram representing the main components of a EOL-PVP: Al frame (10\%), glass (69-75\%), polymers (7-15\%), PV cell (3\%), and metallic filaments $(1 \%)[5,17,18]$.

A literature survey highlights that the difficulties encountered in the degradation of the encapsulant polymer (typically polyethylene-vinyl-acetate (EVA)) represent a major obstacle to the separation of the EOL-PVP components and thus to the efficient recovery of different valuable fractions [5].

The most common recycling methods implemented at pilot and industrial scale rely on mechanical treatments (i.e., dismantling, crushing, and sieving) to achieve the separation of the different PVP components and their concentration in specific size fractions. Typical examples of this approach include the recycling processes proposed by the French environmental services provider Veolia [19], and by the Italian company Nike* S.r.l. [20]. However, these processes are generally defined as 'downcycling' because they can meet the requirements of the EU directive by recovering only low-value fractions (e.g., impure fine-sized glass fractions [17]). This is mainly caused by the fine milling operations required to separate the various EOL-PVPs components from the encapsulant (EVA). Indeed, while enabling the separation of the different EOL-PVP components, these operations are also responsible for the contamination of the separated components by the EVA. This negatively affects the 
economic sustainability of the recycling process by making it possible to recover only low-value impure glass fractions. In order to overcome this limitation, the EU Commission settled specific priorities to promote high-quality recovery operations [21] and founded research and development projects aiming at higher-value material recovery [22].

Some results obtained with this approach include the technologies developed by the Italian company SASIL [23] and by the German Geltz Umwelt-Technologie [24]. Both these technologies are based, again, on mechanical operation but they include a preliminary degradation of the plastic components (i.e., encapsulant and backsheet polymers) by pyrolysis. However, even though facilitating the separation of the PV cell from the encapsulant polymer, this thermal degradation is responsible for the generation of toxic gaseous emissions, mainly due to the fluoride compounds contained in the Tedlar ${ }^{\circledR}$ backsheet (commercial name for Polyvinyl Fluoride based film [25]), which negatively influences the overall environmental impact of the recycling process [26].

A technological solution allowing for the separation of the PV cell, alternative to pyrolysis, is the solvent treatment. Specifically, by virtue of a swelling/dissolution mechanism, the EVA is partly solubilized in the solvent, thereby facilitating the separation of the various PVP components. This method was generally implemented by dipping the entire panel in the solvent bath in absence of solvent agitation, which yielded inefficient mass transfer and thus imposed long treatment times [27-29]. For instance, Doi et al. tested different solvents (i.e., lacquer thinner, toluene, acetone, petroleum benzene, ethanol, methyl ethyl ketone, isopropanol, methyl isobutyl ketone, tetrahydrofuran, trichloroethylene, ethylene glycol, glycerine) at $80^{\circ} \mathrm{C}$ and reported that the best separation performances were obtained by using trichloroethylene in a 10-day treatment [27]. Prado et al. obtained instead the Cell detachment at room temperature by using isopropanol for 2 days [28]. Yan et al. [29], proposed the separation of the various layers constituting the EOL-PVP through a hydrothermal route in $\mathrm{KOH}$-ethanol solution. Nevertheless, the use of these green solutions resulted always in glass fraction still containing EVA residues (low purity glass) [29]. Despite these possible environmental benefits, the solvent treatment remains scarcely implemented due to the slower kinetics with respect to the thermal treatment [27].

Considering that glass and $\mathrm{Al}$ are the main component of the panels (79-85\%), boosting the economic performances and guaranteeing the minimum targets set by regulation require effective strategies oriented toward high purity glass recovery, as well as the recovery of further valuable fractions (e.g., metals contained in the PV cell).

In the previous works by this research group, different approaches for the treatment of EOL-PVPs were investigated [17,30-32]. These studies evidenced that a solvent treatment with cyclohexane can allow effectively recovering a high value glass fraction from crushed PVPs [17]. The possibility to effectively recover impurity-free large sized glass separated from metal contacts and polymeric fraction (including Tedlar ${ }^{\circledR}$, EVA, and PV cell fragments) was demonstrated at pilot scale during the PhotoLife project [33]. During the pilot scale demonstration, mechanical and solvent treatment were performed allowing for the recovery of $\mathrm{Al}$ frames, high-value glass and metallic contacts, while polymeric fractions glued to cell elements (Ag and $\mathrm{Si}$ ) were collected as a solid mixture requiring further refining.

\section{Objectives}

The main objective of this work is assessing the technical and economic feasibility of an upgraded recycling process including the refining of the polymeric-cell mixture. This process, hereafter referred to as 'advanced PhotoLife process', was simulated based on preliminary data derived by lab scale research activities. The process allows for the separation of the polymer fractions and for the recovery of the silver and silicon fractions (Ag and Si) contained in the PV cell. Mass and energy balances are reported and process simulations are analyzed to elaborate a preliminary techno-economic assessment. In this framework, a comparison between the Advanced PhotoLife process and the originally developed PhotoLife process is discussed. 
To the best of our knowledge, recycling strategies allowing the recovery of polymeric fractions have not been reported yet. In fact, they are generally not even considered for recycling [10,27]. Accordingly, process simulations reported here can allow quantifying the economic and environmental benefits that can be derived by the recovery and recycling of these additional materials as secondary raw materials.

\section{Materials and Methods}

\subsection{Mechanical Treatment in Pilot Scale in the PhotoLife Process}

Mass balances and material characterizations were obtained as results of the demonstration campaign performed during the PhotoLife project (www.photolifeproject.eu [33]).

Mechanical and solvent treatments were performed in pilot scale prototypes (Figure 2). Following the manual dismantling of the $\mathrm{Al}$ frames, $82 \mathrm{~kg}$ of panels were shredded (Figure 2A), moved through a cochlea and fed to a system consisting of two vibrating sieves (Figure 2B,C).
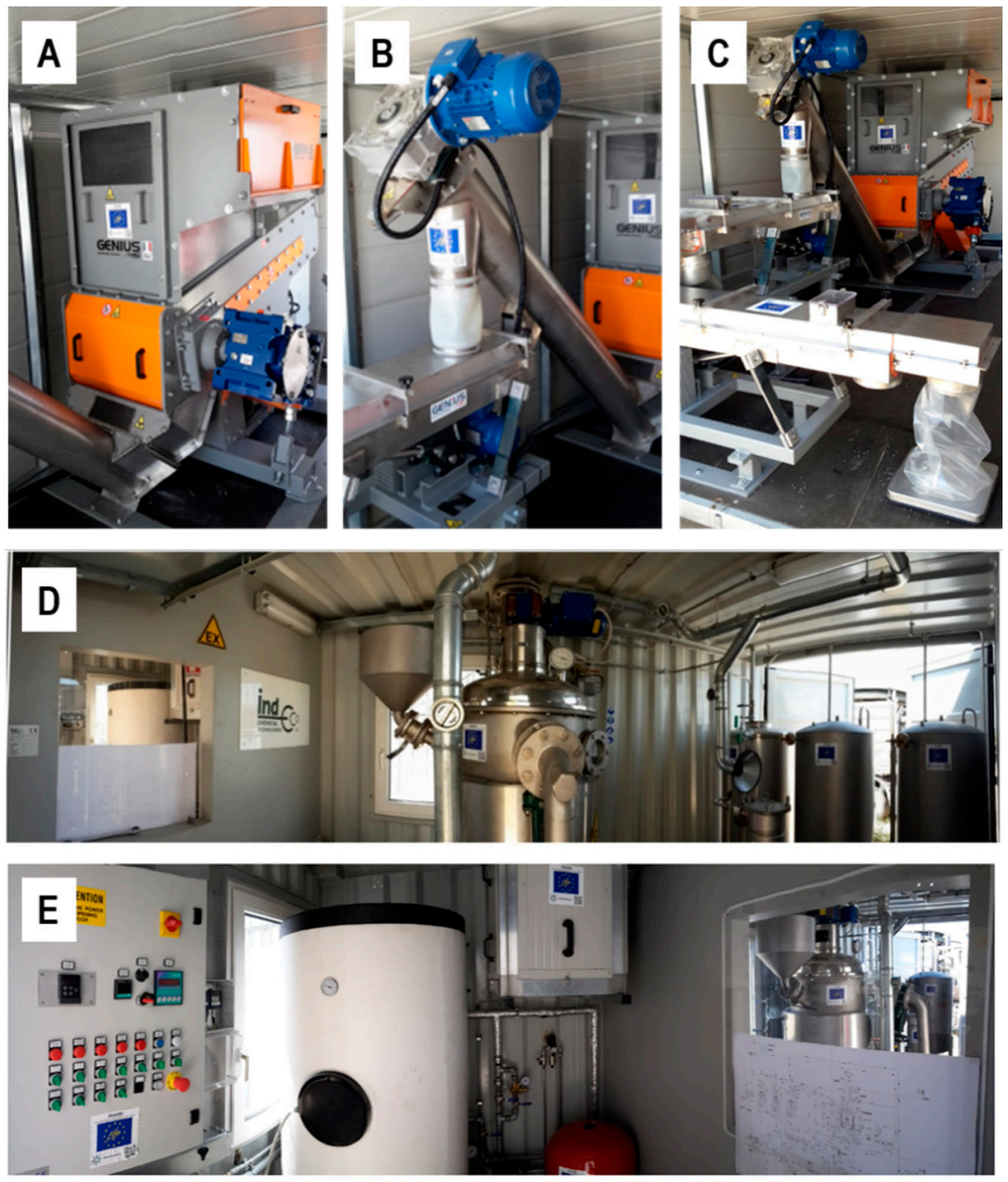

Figure 2. PhotoLife prototypes: container 1 with crusher (A) and vibrosieving (B,C); Container 2 with reactor for solvent treatment and gravimetric separation (D), and control cabin (E).

The vibration sieves include two grids with different size for the separation of three fractions:

- Coarse fraction: $3<x<20 \mathrm{~mm}$;

- Intermediate fraction: $0.5<\mathrm{x}<3 \mathrm{~mm}$;

- Fine fraction: $x<0.5 \mathrm{~mm}$. 


\subsection{Solvent Treatment at Pilot Scale in the PhotoLife Process}

The coarse fraction was further treated in a second prototype using the solvent to detach the different layers glued together in PVP—namely glass, EVA, Tedlar ${ }^{\circledR}$, metal tabbing, and cell material. This prototype was placed inside a second mobile container to allow operation in different locations and control the working area against possible risks due to the use highly flammable hydrocarbons such as the cyclohexane. The container is divided into two isolated zones. The first one (Figure 2D) contains the reagent tanks along with the integrated unit for performing both panel detachment and component separation by sieving and gravimetric separation. The second zone (Figure 2E) contains the control room, the boiler with its hot water circuit, and the fan.

\subsection{Polymers Separation and Metal Recycling in the Advanced PhotoLife Process}

The following EOL Photovoltaic panels were used in the present work: Si-mono (TOPCO Solar Module, TOPCO-230S6; year of manufacturing: 2011) and Si-polycrystalline (Sun Earth, TPB156X156-60-P 240; year of manufacturing: 2012). According to the PhotoloLife process, the EOL-PVPs were manually disassembled to separate the junction box and to recover the Al frames. The panels were then crushed and sieved at pilot scale, as described above. The coarse fraction from sieving was treated with the solvent at lab scale. The solvent treatment was performed at $70{ }^{\circ} \mathrm{C}$ for $2 \mathrm{~h}$ in a jacketed cell reactor $(250 \mathrm{~mL})$ by using $10 \mathrm{~g}$ of crushed material with 1:6 solid/solvent ratio. The stirring was guaranteed by a mechanical stirrer (ArgoLab AM40-D PRO) set approximately at $100 \mathrm{rpm}$.

After the solvent treatment, in the basic PhotoLife (Figure 3), the solvent was recovered by filtration and distillation, while the following two solid fractions were recovered by a gravimetric separation in water: glass and metallic filaments accumulated at bottom of the reactor filled with water, while polymers (EVA and Tedlar ${ }^{\circledR}$ ) with glued PV cell fragments accumulated at the top, i.e., over the free surface of water.

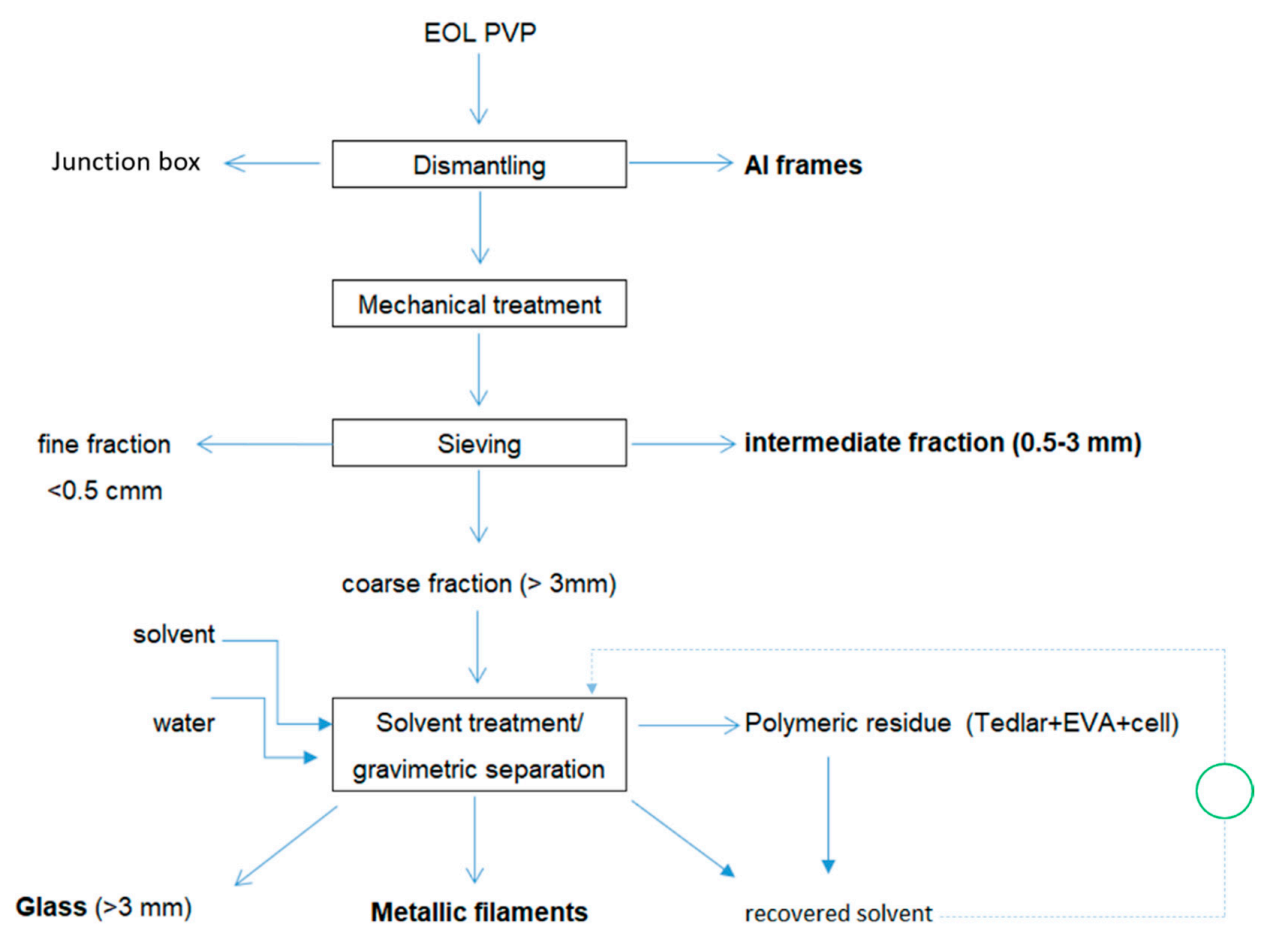

Figure 3. Block diagram of the PhotoLife process: EOL PVP were manually dismantled for removing junction boxes and Al frames; panels were crushed and sieved; coarse fraction was treated by solvent and a gravimetric separation was performed to separate glass and metallic filaments from polymeric residue. 
In the advanced PhotoLife process (Figure 5), the suspension in cyclohexane resulting from the solvent treatment was filtered by employing a wide mesh sieve $(7 \mathrm{~mm})$. In the filtration, the separated Tedlar ${ }^{\circledR}$ fraction was retained in the over-sieve while the under-sieve was composed of cyclohexane, glass, metal contacts and EVA residues (containing the PV cell). The composed under-sieve was then fed to the gravimetric separation and distillation unit. In this unit, a preliminary gravimetric separation (solid/liquid ratio 1:50) enabled the separation of glass from the remaining components. Once the glass was separated, a distillation for the recovery and purification of the solvent was carried out under magnetic stirring within the same reactor at $82{ }^{\circ} \mathrm{C}$. The EVA residues containing the PV cell fragments recovered after the distillation were then thermally treated in a muffle furnace (Nabertherm B410, Tmax $1100{ }^{\circ} \mathrm{C}, 1.2 \mathrm{~kW}$ ) at $650^{\circ} \mathrm{C}$ for $4 \mathrm{~h}$. This operation promoted the polymer degradation/decomposition. The resulting ashes containing the cell residues were recovered and treated by leaching to promote the metals extraction. The leaching tests were carried out in a $250 \mathrm{~mL}$ jacketed cell reactor kept at $60^{\circ} \mathrm{C}$ and magnetically stirred. $\mathrm{HNO}_{3} 1.5 \mathrm{M}(65 \%$, Sigma Aldrich, MO, USA) was employed as leaching agent with a solid to liquid ratio of $30 \mathrm{~mL} / \mathrm{g}$ for $2 \mathrm{~h}$. The leach liquor was then filtered and analyzed by atomic absorption spectrophotometer (AAS, contrAA ${ }^{\circledR}$ 300-Analytik Jena AG, Xenon short arc lamp; flame atomizer fed with a mixture of $\mathrm{C}_{2} \mathrm{H}_{2}$ and air) to assess the metal concentrations. Calibration curves of the investigated metals were performed utilizing a multi-standard solution (Merk Millipore $1000 \mathrm{mg} / \mathrm{L} \mathrm{HNO}_{3}$ sol.). According to a selected wavelength, each metal was determined in three replicates for each measurement. The total metal content in the solid samples was determined by two sequential extraction steps using $\mathrm{HNO}_{3} 65 \%$ as leaching agent in the same experimental conditions as described above.

\subsection{Process Simulations}

The process was simulated in a mixed batch-continuous mode using SuperPro Designer (Intelligen, Inc., Koch Plains, NJ, USA). The manual removal of the aluminum frames from the photovoltaic panels as well as the evaporation of the cyclohexane were simulated as continuous operations. The other physical and hydrometallurgical operations were modeled in batch. Two process options were simulated, a low recycling volume process (LRVP) based on a throughput of 3000 metric tons per year (t/y) of EOL-PVPs, and a high recycling volume process (HRVP) treating 30,000 t/y of EOL-PVPs.

Mass balances for mechanical treatment from pilot scale were used for shredding and sieving operations [34], while experimental results obtained at lab scale were used to model the solvent treatment, polymer separation, and silver leaching. The recovery of silver was simulated based on experimental conditions reported in the scientific literature [35].

\section{Results and Discussion}

\subsection{PhotoLife Process}

The PhotoLife process is described in the block diagram reported in Figure 3. Further details about the operating conditions are reported elsewhere [17].

The process includes the manual dismantling of the $\mathrm{Al}$ frame followed by shredding to produce a target coarse fraction $(>3 \mathrm{~mm})$ as well as residual intermediate and fine fractions. The coarse fraction is further treated by organic solvents, thus resulting in high quality glass ( $>3 \mathrm{~mm}$ ), metallic filaments made of copper, and a polymeric residue containing the PVP back sheet (mainly of Tedlar ${ }^{\circledR}$ ), and the EVA encapsulant still glued to the Si cell fragments (Figure 4). 

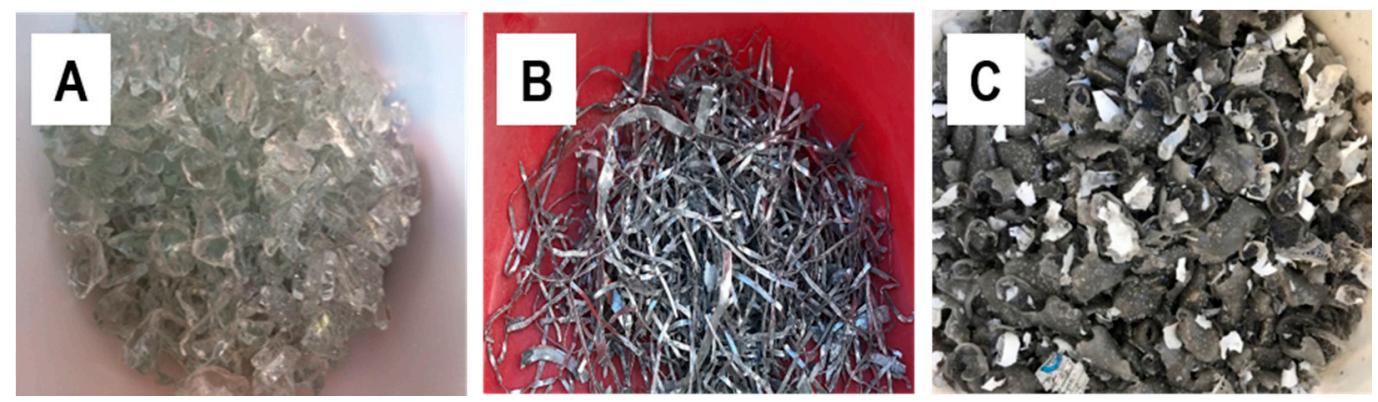

Figure 4. Recovered fractions from solvent treatment operations: solar grade glass (A), metallic filaments (B), and polymeric residue $(\mathbf{C})$.

The $\mathrm{Al}$ from frames, the high quality glass and the metallic filaments can be directly recycled as they are, yielding the first revenue of the PhotoLife process [33]. The intermediate fraction is a by-product without any commercial value, being constituted by fine glass with some metal impurities. This fraction can be re-used in cement production without additional costs for waste disposal/treatment. The fine fraction containing glass, EVA and the cell fine fragment is considered as a waste to be disposed of.

Table 1 reports the mass balances for the different fractions obtained in the PhotoLife process. According to the operation described and the mass balances elaborated during the PhotoLife project, the recycling rate was estimated as reported in Table 2.

Table 1. Mass balance and fraction composition for the PhotoLife process.

\begin{tabular}{|c|c|c|c|c|c|c|c|c|}
\hline \multirow[b]{2}{*}{ Fraction } & \multicolumn{7}{|c|}{ Components } & \multirow[b]{2}{*}{ Weight (kg) } \\
\hline & Glass & $\begin{array}{c}\text { Al } \\
\text { Frames }\end{array}$ & $\begin{array}{l}\text { Metallic } \\
\text { Contacts }\end{array}$ & EVA & Si & Ag & Tedlar ${ }^{\circledR}$ & \\
\hline EOL PVP (100 kg) & 69.5 & 10 & 1.2 & 11.3 & 3.71 & 0.047 & 4.3 & 100 \\
\hline $\mathrm{Al}$ frames & & 10 & & & & & & 10 \\
\hline coarse fraction $(>3 \mathrm{~mm})$ & 44.7 & & 1.2 & 11.3 & 3.30 & 0.042 & 4.3 & 64.8 \\
\hline Glass (>3 mm) & 44.7 & & & & & & & 44.7 \\
\hline metallic filaments & & & 1.2 & & & & & \\
\hline $\begin{array}{c}\text { Polymeric residue }\left(\text { Tedlar }^{\circledR}+\right. \\
\text { EVA }+ \text { cell })\end{array}$ & & & & 9.6 & 3.30 & 0.042 & 4.3 & 19.4 \\
\hline fine fraction $(<0.5 \mathrm{~mm})$ & 5.9 & & & & 0.39 & 0.005 & & 6.3 \\
\hline intermediate fraction $(0.5-3 \mathrm{~mm})$ & 19 & & & & 0.01 & 0.0002 & & 18.9 \\
\hline
\end{tabular}

Table 2. Recycling rate, recovery rate, amount of wastes produced, and recoverable value according to mass balances for the PhotoLife process considering $100 \mathrm{~kg}$ EOL PVP as process input.

\begin{tabular}{ccccc}
\hline Fraction & Recycling (kg) & Recovery (kg) & Wastes (kg) & $\begin{array}{c}\text { Recoverable Value \$ Per } \\
\text { 100 kg EOL PVP }\end{array}$ \\
\hline Al frames & 10 & 10 & & 8.3 \\
Glass $(>3 \mathrm{~mm})$ & 45 & 45 & & 2.5 \\
Metallic filaments & 1.2 & 1.2 & 19 & \\
Polymeric residue & & & 6 & 0 \\
Fine fraction $(<0.5 \mathrm{~mm})$ & 19 & 19 & 25 & 22 \\
Intermediate fraction $(0.5-3 \mathrm{~mm})$ & 75 & 75 & & $30 \%$ \\
\hline TOTAL & $75 \%$ & $75 \%$ &
\end{tabular}

In the PhotoLife project, the thermal treatment of plastic residue was not evaluated because, without preliminary separation of Tedlar ${ }^{\circledR}$ from EVA, such an operation is not feasible. In fact, Tedlar ${ }^{\circledR}$ contains fluoride, which can release toxic HF gas emissions during thermal valorization. For this reason, the recovery rate for the PhotoLife process is equal to the recycling rate (Table 2). 
Indications about the performances of the recycling process can be derived by estimating the percentage of the maximum recoverable value that is attained, i.e., the value of the recovered materials divided by the value of all the materials contained in the panels.

Considering the main components reported in Table 3 and their market prices (https://www. capitalscrapmetal.com/prices/; https://www.dailymetalprice.com), it is found that large part of the maximum recoverable value is associated to the silver fraction contained in the PVP wastes of the PhotoLife recycling route. Accordingly, the PhotoLife process allows for only $30 \%$ recovery of maximum recoverable value (Table 2), the largest part of the recoverable value being associated to the polymeric residue containing Ag and Si (Table 3).

Table 3. Recycling rate, recovery rate, amount of wastes produced, and recoverable value according to mass balances for the PhotoLife process.

\begin{tabular}{|c|c|c|c|c|}
\hline Recycled Component & $\begin{array}{c}\text { Weight } \\
\text { (kg in } 100 \mathrm{~kg} \text { EOLPVP) }\end{array}$ & $\begin{array}{l}\text { Market Price } \\
(\$ / \mathbf{k g})\end{array}$ & $\begin{array}{c}\text { Estimated Value } \\
\text { (\$ per } 100 \text { kg EOLPVP) }\end{array}$ & $\%$ Value \\
\hline Al frames & 10 & 0.8 & 8.3 & 11.5 \\
\hline Metallic filaments & 1.2 & 2.4 & 2.8 & 3.9 \\
\hline High quality glass & 69.5 & 0.2 & 16.4 & 22.8 \\
\hline Tedlar $^{\circledR}$ & 4.3 & 0.001 & 0.005 & 0.008 \\
\hline $\mathrm{Ag}$ & 0.047 & 708 & 33.5 & 46.6 \\
\hline $\mathrm{Si}$ & 3.71 & 3.0 & 10.9 & 15.2 \\
\hline TOTAL & 88 & & 72 & \\
\hline
\end{tabular}

\subsection{Advanced PhotoLife Process}

According to the illustrated analysis, the process was implemented to improve the recycling and recovery targets by:

- Separating the different polymers in the polymeric residue

- $\quad$ Recycling the Tedlar ${ }^{\circledR}$ backsheet

- Thermally treating the EVA residues

- $\quad$ Recycling the Ag and Si from the ashes

The additional unit operations required to perform this process are described in Figure 5. The process includes the separation of Tedlar ${ }^{\circledR}$ by sieving, followed by the gravimetric separation in water of EVA residue (overflow) and glass (downflow). The EVA residue containing the Si cell fragments and Ag from the printed contacts is then thermally treated to burn the EVA. Hydrometallurgical treatment of the residual ashes is finally performed to recover Ag and Si.

The mass balances of the Advanced PhotoLife process are reported in Table 4.

Table 4. Mass balance and fraction composition for the advanced PhotoLife process.

\begin{tabular}{|c|c|c|c|c|c|c|c|c|}
\hline \multirow[b]{2}{*}{ Fraction } & \multicolumn{7}{|c|}{ Components } & \multirow[b]{2}{*}{ Weight (kg) } \\
\hline & Glass & $\begin{array}{c}\text { Al } \\
\text { Frames }\end{array}$ & $\begin{array}{l}\text { Metallic } \\
\text { Contacts }\end{array}$ & EVA & Si & Ag & Tedlar ${ }^{\circledR}$ & \\
\hline EOL PVP (100 kg) & 69.5 & 10 & 1.2 & 11.3 & 3.71 & 0.047 & 4.3 & 100 \\
\hline $\mathrm{Al}$ frames & & 10 & & & & & & 10 \\
\hline Coarse fraction $(>3 \mathrm{~mm})$ & 44.7 & & 1.2 & 11.3 & 3.30 & 0.042 & 4.3 & 64.8 \\
\hline Glass $(>3 \mathrm{~mm})$ & 44.7 & & & & & & & 42 \\
\hline$>$ Metallic filaments & & & 1.2 & & & & & 1.2 \\
\hline Tedlar $^{\circledR}$ & & & & & & & 4.3 & 4.3 \\
\hline Polymeric residue (EVA + cell) & & & & 9.6 & 3.30 & 0.042 & & 12.9 \\
\hline Metal bearing ashes & & & & & 3.30 & 0.042 & & 3.34 \\
\hline $\mathrm{Ag}$ & & & & & & 0.032 & & 0.032 \\
\hline $\mathrm{Si}$ & & & & & 3.30 & & & 3.30 \\
\hline Fine fraction $(<0.5 \mathrm{~mm})$ & 5.9 & & & & 0.39 & 0.005 & & 6.3 \\
\hline Intermediate fraction $(0.5-3 \mathrm{~mm})$ & 18.9 & & & & 0.01 & 0.0002 & & 18.9 \\
\hline EVA & & & & 1.7 & & & & 1.7 \\
\hline
\end{tabular}




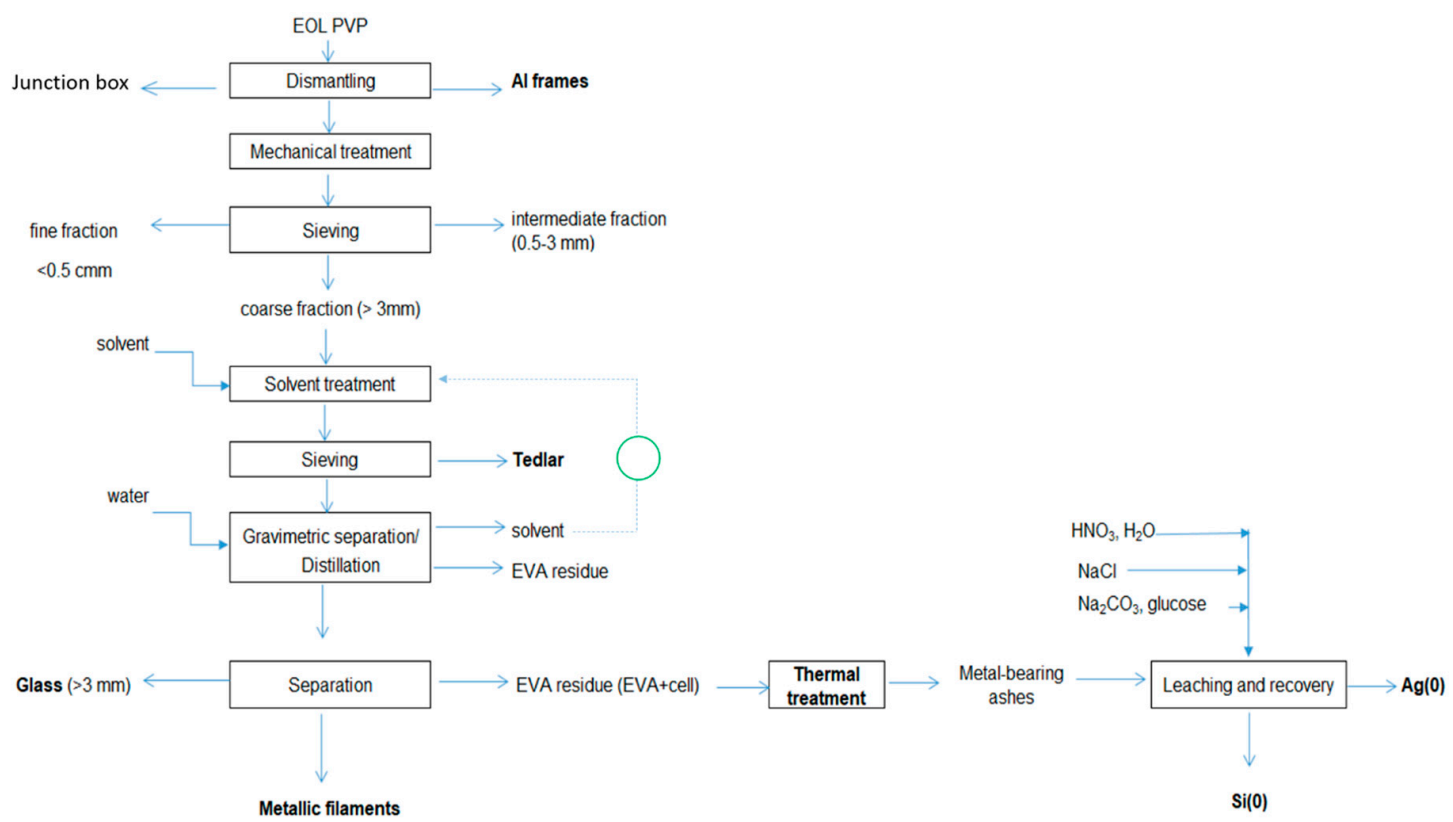

Figure 5. Block diagram of the advanced PhotoLife process.

Reported results indicates that, as compared to the original PhotoLife process, the advanced PhotoLife process allows for a significant improvement in both the recycling and the recovery rate. This leads to a significant increase in the recovered value, which reaches $75 \%$ of maximum theoretical value (Table 5). This increase in the recovered value is mainly due to the increased recovery of the Ag panel fraction, $90 \%$ of this latter fraction is contained in the ashes fed to the hydrometallurgical treatment and can thus effectively recovered through the proposed process scheme.

Table 5. Recycling rate, recovery rate amount of wastes produced, and recoverable value according to mass balances for the advanced PhotoLife process for $100 \mathrm{~kg}$ of EOL PVP as input.

\begin{tabular}{|c|c|c|c|c|}
\hline Fraction & Recycling (kg) & Recovery (kg) & Wastes $(\mathbf{k g})$ & $\begin{array}{c}\text { Recoverable Value } \$ \text { per } \\
100 \mathrm{~kg} \text { EOL PVP }\end{array}$ \\
\hline Al frames & 10 & 10 & & 8.3 \\
\hline Glass (>3 mm) & 45 & 45 & & 10.5 \\
\hline Metallic filaments & 1.2 & 1.2 & & 2.8 \\
\hline Tedlar $^{\circledR}$ & 4.3 & 4.3 & & 0.006 \\
\hline Polymeric residue (EVA + cell) & & 9.6 & & \\
\hline $\mathrm{Ag}$ & 0.032 & 0.032 & & 22.7 \\
\hline $\mathrm{Si}$ & 3.3 & 3.3 & & 97 \\
\hline Fine fraction $(<0.5 \mathrm{~mm})$ & & & 6 & \\
\hline Intermediate fraction $(0.5-3 \mathrm{~mm})$ & 19 & 19 & & 0.0 \\
\hline EVA & & 1.7 & & \\
\hline TOTAL & 82 & 94 & 6 & 54 \\
\hline$\%$ RATE & $82 \%$ & $94 \%$ & & $75 \%$ \\
\hline
\end{tabular}

\subsection{Process Simulations}

Process simulations were performed for the advanced PhotoLife process at two potentialities (3000 and 30,000 t/y). For both these options, the batch duration was set as $5.5 \mathrm{~h}$ with a cycle time (time between two subsequent batches) of $4.65 \mathrm{~h}$. It is important to remark that this time does not correspond to the minimum cycle time, which would be instead as low as $2.17 \mathrm{~h}$ based on the longest operation (process bottleneck) of water-cyclohexane density separation (total time: $2.17 \mathrm{~h}$ ). The cycle time was set as 4.65 based on the assumption to conduct five batches per day for a total of 330 days. The concept of performing five batches per day is associated with the idea of a recycling plant working on two 8-h shifts. Based on these assumptions, the increase in recycling volume from 
3000 to $30,000 \mathrm{t} / \mathrm{y}$ would be ensured by the same number of batches per year with larger throughputs per batch, thus larger equipment and more labor required. In the simulation, the duration of the batch cycle was maintained the same despite the tenfold increase in process throughputs. However, the labor required to implement the process was increased to account for the larger number of operators associated with the operation of EOL-PVPs reception, storage, manual dismantling, as well as material transfer between operations.

As for the equipment size and cycle time, the downstream hydrometallurgical section of the process required special consideration. For this section, the cycle time between two batches was set considerably higher than the upstream batch section, based on the assumption that the hydrometallurgical section would process the materials generated by multiple batches of the upstream process. In particular, for the process that recycles 30,000 $\mathrm{t} / \mathrm{y}$, the cycle time in the hydrometallurgical section was set as $24 \mathrm{~h}$. This means that the hydrometallurgical section in this process would treat altogether the material generated in 1 day by five batches of the upstream process. In contrast, this cycle time for the LRVP was set as $240 \mathrm{~h}$. Given the 10 times lower throughputs in the LVRP, the 10-fold increase in this cycle time implies that each hydrometallurgical batch treats the same amount of material. This choice is due to the consideration that the equipment required to treat the amount of material fed to the hydrometallurgical section (about 3\% of the EOL-PVPs) would be too small and non-optimal given the non-linear increase in equipment cost and labor required to treat increased amount of material. In other words, treating lower amounts of materials more frequently (higher number of batches) was considered as less efficient than treating the same total amount per year with a lower frequency but in larger batches.

The net profit value was calculated at an interest rate of $0.5 \%$ over a project lifetime of 15 years that includes a plant construction period of 30 months and a startup period of 4 months. The cash-flow analysis was also conducted under the assumption of an inflation rate of $1 \%$, an income tax of $40 \%$ and a depreciation time of 7 years. Such a depreciation time was set based on an overall plant depreciation coefficient of $15 \%$. Such a coefficient value was adopted based on current Italian legislation (Ministerial Decree 31 December 1988) that sets as 10\% the depreciation coefficient for large mechanical machines, at $12 \%$ the one for electricity generation plants, engines and pumps, and at $17.5 \%$ the one for chemical equipment within the metallurgy industry.

A comparison between the economic outputs of the two processes is listed in Table 6 evidencing that the advanced Photolife process is economically feasible only treating $30,000 \mathrm{t} / \mathrm{y}$.

Table 6. Economic outputs of the process for the two recycling volumes.

\begin{tabular}{ccc}
\hline Recycling Volume (t/y of EOL-PVPs) & $\mathbf{3 0 0 0}$ & $\mathbf{3 0 , 0 0 0}$ \\
\hline Total Capital Investment (\$) & $5,459,000$ & $10,427,000$ \\
Capital Investment Charged to This Project (\$) & $5,459,000$ & $10,427,000$ \\
Operating Cost (\$/y) & $6,882,000$ & $25,561,000$ \\
Main Revenue (\$/y) & 269,000 & $2,690,000$ \\
Other Revenues (\$/y) & $2,667,744$ & $26,677,441$ \\
Total Revenues (\$/y) & $2,937,000$ & $29,367,000$ \\
Cost Basis Batch Rate (t UPRF) & 1.76 & 17.62 \\
Cost Basis Annual Rate (t UPRF/y) & 3000 & 30,000 \\
Unit Processing Cost (t UPRF/y) & 2294.11 & 852.04 \\
Net Unit Processing Cost (t UPRF/y) & 2294.11 & 852.04 \\
Unit Processing Revenue (t UPRF/y) & 978.90 & 978.90 \\
Gross Margin (\%) & -145.52 & 11.37 \\
Return on Investment (\%) & -68.95 & 28.89 \\
Payback Time (y) & N/A & 3.35 \\
IRR (After Taxes) (\%) & N/A & 9.61 \\
NPV (at 1.0\% Interest) (\$) & $-49,783,000$ & $14,275,000$ \\
\hline
\end{tabular}

IRR = internal rate of return; NPV = net present value; URPF = unit production reference flow. 
While treating 3000 ton of end-of-life photovoltaic panels per year does not yield enough revenues to sustain the operating costs (about $3 \mathrm{M} \$$ revenues against $7 \mathrm{M} \$$ operating costs), treating $30,000 \mathrm{t} / \mathrm{y}$ is sufficient to sustain the process and repay the investment within 3-3.5 years. It is evident that the 10 -fold increase in the recycling volumes results in a linear increase in process revenues from about $3 \mathrm{M} \$ / \mathrm{y}$ to $30 \mathrm{M} \$ / \mathrm{y}$. At the same time, the capital investment increases only by 2 times, from about 5 to $10 \mathrm{M} \$$, thus contributing to a higher return on the investment. Such an increase in total capital investment is due to (i) the non-linear relationship between equipment cost and size, which is known to follow a power law with exponent around 0.5-0.6 [36,37], and (ii) the hydrometallurgical section sized for the same throughput but working only part of the time (1/10).

Table 6 also denotes a fourfold increase in operating costs despite the 10 times higher throughput by scaling-up from LRVP to HRVP. This aspect requires a special analysis since having operating costs higher than revenues results in the LRVP not being economically feasible. Analyzing and understating how this cost item affects the process economy requires breaking it down into the different components.

The operating cost breakdown is shown in Figure 6, which highlights that labor represents around $71 \%$ and $64 \%$ of the operating costs for the LRVP and HRVP, respectively.

(a)

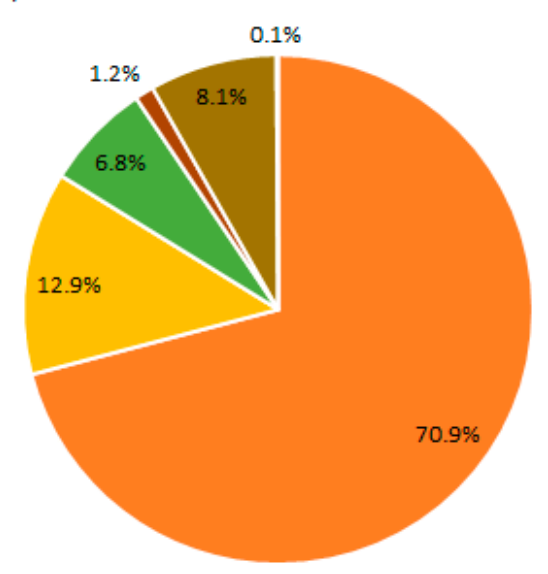

(b)

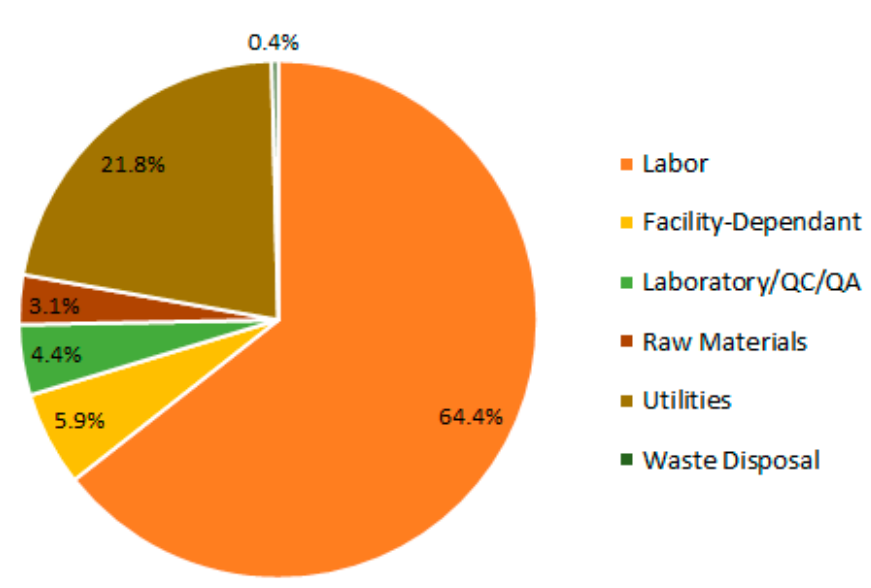

Figure 6. Operating cost breakdown for 3000 (a) and 30,000 (b) t/y simulations.

The lower impact of the labor cost in the HRVP is associated with the increase in labor costs which increase nonlinearly with increasing the throughput. Indeed, the total labor cost comprises a component that is linearly proportional to the throughput and a component that increases only slightly, i.e., less than proportionally, with it. The first one is for instance associated with the manual work required for the manual removal of the aluminum frames from the EOL PVPs. The second one is instead the labor associated with the physical and chemical/hydrometallurgical operations, which was assumed to increase to a lower extent with the process throughput (i.e., filter-presses and reactors might require only 1 or 2 more operators despite the 10-fold increase in recycling volume). Improved understanding of the relationship between labor and process economy can be obtained by analyzing the labor cost breakdown (Figure 7).

Figure 7 displays through labels the amount of labor-hours per year associated with each process section, evidencing that the largest portion of labor cost is associated with the manual dismantling of the aluminum frames. 


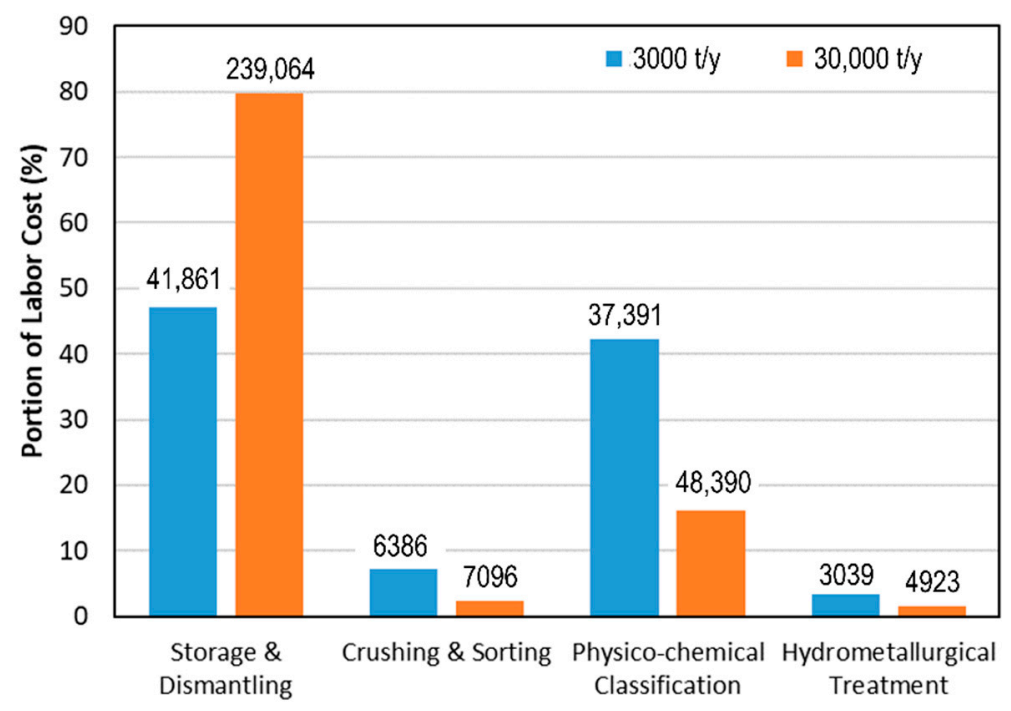

Figure 7. Labor cost breakdown among the different process sections. The numbers on the histogram bars represent the total hour of labor hours required per year.

Figure 7 also evidences that the total amount of labor-hours per year required to run the process are about 88,000 and 299,000 for the LRVP and HRVP, respectively. For the LRVP, this corresponds to have on-site about 17 people at any time. For the HRVP, the same consideration leads to a total of 56 people present on the plant during each shift, which might be overestimated. However, the fact that the labor for the latest option might have been overestimated represents further corroborates the conclusion that the HRVP is economically feasible.

It must be also remarked that the simulations were performed under the assumption of a high recycling rate (99\%) of cyclohexane and water. Attaining this recycling rate for water and solvent is essential to minimize the costs for material consumption and waste disposal and thus enforce the economic feasibility in the HRVP.

More detailed information about materials balance for both recycling volumes are listed in Table 7 , whereas the purchasing and selling prices of raw materials and the process revenues are listed in Table 8.

Table 7. Material balance of the process for the two recycling volumes (negative values represent consumed materials whereas positive values represent produced materials).

\begin{tabular}{|c|c|c|}
\hline Recycling Volume (t/y) & 3000 & 30,000 \\
\hline Cyclohexane $(t / y)$ & -57 & -570.12 \\
\hline Glucose $(t / y)$ & -0.42 & -4.17 \\
\hline $\mathrm{HNO}_{3} 5 \mathrm{M}(\mathrm{t} / \mathrm{y})$ & -0.152 & -1514.93 \\
\hline $\mathrm{Na}_{2} \mathrm{CO}_{3}(\mathrm{t} / \mathrm{y})$ & -404 & -4.04 \\
\hline $\mathrm{NaCl}(\mathrm{t} / \mathrm{y})$ & -1976 & -19.76 \\
\hline $\mathrm{NaOH}(\mathrm{t} / \mathrm{y})$ & 8515 & -8.33 \\
\hline Water $\left(\mathrm{m}^{3}\right)$ & -346.00 & -3470.17 \\
\hline Acetic Acid (t/y) & +76.67 & +766.65 \\
\hline $\operatorname{Ag}(t / y)$ & +1.28 & +12.81 \\
\hline Aluminum Frames $(t / y)$ & +300.00 & +3000.00 \\
\hline $\mathrm{Cu}-\mathrm{Al}(\mathrm{t} / \mathrm{y})$ & +36.00 & +360.00 \\
\hline Glass $(>3 \mathrm{~mm})(\mathrm{t} / \mathrm{y})$ & 1344.8 & $+13,444.00$ \\
\hline Si $(t / y)$ & +111.00 & +1110.00 \\
\hline $\operatorname{Tedlar}^{\circledR}(\mathrm{t} / \mathrm{y})$ & +129.00 & +1290.00 \\
\hline
\end{tabular}


Table 8. Purchasing prices of raw materials and selling prices of revenues.

\begin{tabular}{ccc}
\hline Type & Material & $\begin{array}{c}\text { Cost } \\
\mathbf{( \$ / k g )}\end{array}$ \\
\hline \multirow{4}{*}{ Raw Materials } & Cyclohexane & 1.00 \\
& $\mathrm{Glucose}$ & 0.00 \\
& $\mathrm{HNO}_{3} 5 \mathrm{M}$ & 0.14 \\
$\mathrm{Na}_{2} \mathrm{CO}_{3}$ & 0.20 \\
& $\mathrm{NaCl}$ & 0.02 \\
& $\mathrm{NaOH}$ & 0.25 \\
& Water & 1.50 \\
\hline \multirow{3}{*}{ Revenues } & EOL-PVP & 0.5 \\
& $\mathrm{Glass}$ & 0.2 \\
& $\mathrm{Si}$ & 2.8 \\
& $\mathrm{Ag}$ & 600 \\
& $\mathrm{Cu}-\mathrm{Al}$ & 2 \\
\hline & Aluminum Frame & 0.7
\end{tabular}

It must be remarked that EOL-PVPs were not considered as raw materials in the simulation but as revenues. This choice can be justified by considering that the recyclers receive from the community/collectors/PVP producers a fee to sustain the economy of the recycling process. This fee is usually paid by PVP consumers by charging with an overprice of about $10 \$ / \mathrm{PVP}$ the cost for the purchase and installation of PVPs. Since the average PVP weight is around $20 \mathrm{~kg} / \mathrm{PVP}$, such fee ultimately translates into a gross income contribution for recyclers of about $0.5 \$ / \mathrm{kg}$.

\section{Discussion}

The technical feasibility of the PhotoLife process was demonstrated at pilot scale. This process allows recovering high-value solar glass and $\mathrm{Al}$ and $\mathrm{Cu}$ scraps with $75 \%$ recovery rate, thus fulfilling targets set by the EU Directive (70\% until 2018 now increased to $80 \%$ ).

On the other hand, the PhotoLife process did not include any material recovery from a residual fraction composed of the panel polymers (EVA and Tedlar ${ }^{\circledR}$ ) and of the cell components. In this latter fraction, it is concentrated about $90 \%$ of the whole Ag panel content, which account for most of the panel recoverable value. Accordingly, by excluding metal recovery from this residual fraction, the Photolife process delivered secondary raw materials (high quality glass, $\mathrm{Al}$ and $\mathrm{Cu}$ ) covering only $30 \%$ of the PVP recoverable value.

Preliminary lab scale tests were performed demonstrating the possibility to separate the polymeric components (EVA and Tedlar ${ }^{\circledR}$ ) and to recycle the metals found in the cell fragments (Ag and $\mathrm{Si}$ ), thereby improving the process performances. The proposed process solution includes the physical separation of the Tedlar ${ }^{\circledR}$ backsheet materials followed by the thermal decomposition of EVA. $\mathrm{Ag}$ and Si can be then recovered by hydrometallurgical treatment of the ashes left after EVA thermal treatment. This process can increase both the recycling rate $(82 \%)$ and the recovered value $(75 \%$ of the panel recoverable value), giving at the same time the possibility to produce an excess of energy (from EVA combustion) needed for other process operations such as solvent treatment and leaching (advanced Photolife process material recovery rate is $94 \%$, thus exceeding the EU target that is $85 \%$ ).

Process simulations at two feed rates (Table 6) denoted that the advanced PhotoLife process is economically feasible only treating 30,000 t/y of EOL PVP. This is due mainly to economy scale law decreasing the impact of plant cost per produced unit for increased size, but there is also a critical aspect in the hydrometallurgical section in the LRVP whose size was chosen avoiding small equipment with expensive controls. This leads to a working time for this section that is only $1 / 10$ of the time, which is not an efficient operating solution. Therefore, aiming to recycle $3000 \mathrm{t} / \mathrm{y}$ of EOL-PVPs, an alternative solution to make the process economically feasible would be to exclude from the investment the hydrometallurgical section and sell the Ag-Si-EVA material to external processers. 
Operating costs break down evidenced that labor costs are the main components (Figure 6). Analyzing the different labor contribution it is also evident that dismantling activity of the external frames is the largest one (Figure 7). This is a crucial aspect to be considered in the techno-economic assessment of the developed process as it represents a limiting factor for the scale-up. Pilot-scale tests highlighted as one operator can manually remove the frame from one EOL-PVP in $5 \mathrm{~min}$. Given the average weight of $20 \mathrm{~kg} / \mathrm{EOL}-\mathrm{PVP}, 1$ labor hour produces the dismantling of $240 \mathrm{~kg}$ of EOL-PVPs. The manual removal of the aluminum frame from PVP can be thus considered as a time-cost constraint in the process. For this reason, it was simulated as a continuous operation taking place $24 / 7$ for 330 days/y. This consideration implies that increasing the process throughput from 3000 to $30,000 \mathrm{t} / \mathrm{y}$ requires a linear increase in the labor hours at the manual dismantling from 1.58 to 16.13 per hour. In other words, the batch feed of 1.59 ton per hour of dismantled EOL-PVPs in the LRVP can be obtained by having 1.58 labor hour per hour while the $16.20 \mathrm{t} / \mathrm{y}$ in the HRVP requires having 12.13 labor hour per hour. This constraint also suggests that an increase in the process feasibility could be attained by replacing the manual removal of the frames with an automated and faster technology.

For the above-mentioned reasons, the only labor considered to increase linearly by scaling up 10 times the process is the one for manual dismantling. The labels in Figure 7 highlights the labor hours per year associated with this section increases by 5.7 times by scaling up the process from 3000 to $30,000 \mathrm{t} / \mathrm{y}$ of EOL-PVPs (the increase is not exactly linear to the scale-up because it contains the non-linear labor for EOL-PVPs handling and storage). In contrast, the other labor requirement accounted only for a few extra-people to face the larger throughput. Clearly, the 4-fold increase in operating costs observed by scaling-up 10 times the process arisen from a balance between these two kinds of costs. Furthermore, the fourfold increase in operating costs despite the 10 times higher recycling volume actually suggests as the sum of all costs that are linearly proportional to the throughput (e.g., manual dismantling, raw materials, utilities, etc.) are slightly lower than the others.

In order to improve economic feasibility of the process the automatization of frames removal seems to be the best option.

A final consideration about energy balances from simulations that highlighted another interesting feature of the advanced Photolife process: the thermal treatment of the EVA offers a significant energy credit. In particular, considering the simulation at 30,000 t/y, the exothermic thermal degradation of EVA (calorific value $-45 \mathrm{~kJ} / \mathrm{g}$ [38]) would produce about $12.5 \mathrm{MWh} / \mathrm{batch}$ that could be conveniently recovered where needed across the flowsheet. Then, according to a possible energy recovery scheme, part of this energy can be recovered to heat up the leaching reactor and the cyclohexane evaporator, requiring 0.025 and $1.4 \mathrm{MWh} / \mathrm{batch}$, respectively. However, the recovered heat would still correspond only to the $11 \%$ of the total energy credit $(12.5 \mathrm{MWh} / \mathrm{batch})$, thus leaving a theoretical surplus of about $11 \mathrm{MWh} / \mathrm{batch}$ available for other heating tasks (for instance thermal conditioning of cyclohexane having a fusion point of $7^{\circ} \mathrm{C}$ ). Then including thermal valorization of EVA the energy consumption of the recycling process is reduced and the recovery targets achieved. Otherwise not including this operation, recovery rate (sum of recycled materials plus material used for energy production) would be the same than recycling rate ( $82 \%)$ not satisfying EU target $(85 \%)$.

\section{Conclusions}

In this work, two processes (the Photolife process and the advanced Photolife process) for EOL PVP treatment were compared in terms of recycling rate, recovery rates and recoverable value rate.

The Photolife process was implemented at pilot scale demonstrating the technical feasibility of the operations allowing for the recovery of high value glass and metals from frames and metallic contacts. Nevertheless, the PhotoLife process did not include the recycling (or recovery) of polymers and metals from the cells (including Ag and Si).

Mass balances of the processes evidenced that the integration in the advanced Photolife process of operations for polymer separation, EVA combustion and Ag-Si recycling can greatly improve both recycling rate (from $75 \%$ to $82 \%$ ) and recoverable value (from $30 \%$ to $75 \%$ ). Then, according to 
preliminary lab scale tests, the advanced Photolife process exceeded EU targets in terms of recycling rate $(82 \%$ vs. $80 \%)$ and recovery rate $(94 \%$ vs. $85 \%)$ guaranteeing high value products recycling.

The simulations for the advanced PhotoLife process highlighted its economic feasibility only at high recycling volume $(30,000 \mathrm{t} / \mathrm{y})$. By recycling 30,000 ton of EOL-PVPs per year, the return of the investment would be about $29 \%$ with a NPV at $1 \%$ interest of $14,275,000 \$$.

The main throughput/economic constraint in the process is represented by the manual work required to remove the $\mathrm{Al}$ frames from the EOL-PVPs. Replacing this manual work with automated operations might improve considerably the process economy and probably make the process feasible also at lower recycling volumes.

Another point for further optimization is the hydrometallurgical section of the recycling process/plant, whose economy could be significantly improved by avoiding long inactive times between batches. This could be obtained by developing a multi-waste process treating not only PVP but also other silver-rich wastes such as Ag-batteries.

Further simulations will address the effect of these options (automatization of dismantling and inclusion of the treatment of Ag-containing wastes) on the economic feasibility of the advanced PhotoLife process for different flow rates.

Author Contributions: Conceptualization, F.P., P.A., E.M. and L.T.; Methodology, A.R., L.B. and G.G.; Software, G.G.; Validation, E.M., L.B. and P.A.; Formal analysis, L.B.; Investigation, A.R.; Data curation, A.R., G.G. and L.B.; Writing-original draft preparation, A.R.; Writing-review and editing, F.P. All authors have read and agreed to the published version of the manuscript.

Funding: This work was co-funded by the Italian Ministry of the Environment and Sea Protection within the ORIFO project activities, which has foreseen the implementation of the end-of-life photovoltaic panels recycling process developed in the previous European project PHOTOLIFE (LIFE13 ENV/IT/001033), co-funded by EU LIFE+ program.

Conflicts of Interest: The authors declare no conflict of interest. The funders had no role in the design of the study; in the collection, analyses, or interpretation of data; in the writing of the manuscript, or in the decision to publish the results.

\section{References}

1. Holdren, J.P. Energy and Sustainability. Science 2007, 315, 737. [CrossRef] [PubMed]

2. Tao, J.; Yu, S. Review on feasible recycling pathways and technologies of solar photovoltaic modules. Sol. Energy Mater. Sol. Cells 2015, 141, 108-124. [CrossRef]

3. SPE. Global Market Outlook. Available online: https:/www.solarpowereurope.org/wp-content/uploads/ 2018/09/Global-Market-Outlook-2018-2022.pdf (accessed on 21 July 2020).

4. IRENA; IEA-PVPS. End of Life Management: Solar Photovoltaic Panels. Available online: https://www.irena. org/publications/2016/Jun/End-of-life-management-Solar-Photovoltaic-Panels (accessed on 21 July 2020).

5. Padoan, F.C.S.M.; Altimari, P.; Pagnanelli, F. Recycling of end of life photovoltaic panels: A chemical prospective on process development. Sol. Energy 2019, 177, 746-761. [CrossRef]

6. Paiano, A. Photovoltaic waste assessment in Italy. Renew. Sustain. Energy Rev. 2015, 41, 99-112. [CrossRef]

7. Sapra, G.; Chaudhary, V.; Kumar, P.; Sharma, P.; Saini, A. Materials Today: Proceedings Recovery of silica nanoparticles from waste PV modules. Mater. Today Proc. 2020, 6-11. [CrossRef]

8. Corcelli, F.; Ripa, M.; Ulgiati, S. End-of-life treatment of crystalline silicon photovoltaic panels. An emergy-based case study. J. Clean. Prod. 2017, 161, 1129-1142. [CrossRef]

9. EU. Directive 2012/19/EU of the European Parliament and of the Council of 4 July 2012 on Waste Electrical and Electronic Equipment (WEEE) (Recast). Available online: https:/eur-lex.europa.eu/legal-content/EN/ TXT/PDF/?uri=CELEX:32012L0019\&from=EN (accessed on 21 July 2020). 
10. U.S. EPA. Solid Waste Management and Green House Gases: A Life Cycle Assessment. Available online: https://nepis.epa.gov/Exe/ZyNET.exe/60000AVO.TXT?ZyActionD=ZyDocument\& Client=EPA\&Index $=2006+$ Thru $+2010 \&$ Docs $=\&$ Query $=\&$ Time $=\&$ EndTime $=\&$ SearchMethod $=1 \&$ TocRestrict $=$ n $\&$ Toc $=\&$ TocEntry $=\& Q$ Field $=\& Q F i e l d$ Year $=\& Q F i e l d M o n t h=\& Q F i e l d D a y=\& I n t Q F i e l d O p=$ 0\&ExtQFieldOp=0\&XmlQuery=\&File=D\%3A\%5Czyfiles\%5CIndex\%20Data\%5C06thru10\%5CTxt\% 5C00000000\%5C60000AVO.txt\&User=ANONYMOUS\&Password=anonymous\&SortMethod=h\%7C\&MaximumDocuments=1\&FuzzyDegree=0\&ImageQuality=r75g8/r75g8/x150y150g16/i425\&Display= hpfr\&DefSeekPage=x\&SearchBack=ZyActionL\&Back=ZyActionS\&BackDesc=Results\%20page\& MaximumPages=1\&ZyEntry=1\&SeekPage=x\&ZyPURL\# (accessed on 21 July 2020).

11. Gerbinet, S.; Belboom, S.; Léonard, A. Life Cycle Analysis (LCA) of photovoltaic panels: A review. Renew. Sustain. Energy Rev. 2014, 38, 747-753. [CrossRef]

12. Frischknecht, R.; Heath, G.; Raugei, M.; Sinha, P.; de Wild-Scholten, M. Methodology Guidelines on Life Cycle Assessment of Photovoltaic Electricity. Available online: https://iea-pvps.org/wp-content/uploads/ 2020/01/rep12_11.pdf (accessed on 21 July 2020).

13. Mahmoudi, S.; Huda, N.; Alavi, Z.; Islam, M.T.; Behnia, M. End-of-life photovoltaic modules: A systematic quantitative literature review. Resour. Conserv. Recycl. 2019, 146, 1-16. [CrossRef]

14. Tao, M.; Fthenakis, V.; Ebin, B.; Steenari, B.; Butler, E.; Sinha, P.; Corkish, R.; Wambach, K.; Simon, E.S. Major challenges and opportunities in silicon solar module recycling. Prog. Photovolt. Res. Appl. 2020, pip.3316. [CrossRef]

15. Tsanakas, J.A.; Heide, A.; Radavičius, T.; Denafas, J.; Lemaire, E.; Wang, K.; Poortmans, J.; Voroshazi, E. Towards a circular supply chain for PV modules: Review of today's challenges in PV recycling, refurbishment and re-certification. Prog. Photovolt. Res. Appl. 2020, 28, 454-464. [CrossRef]

16. Lunardi, M.M.; Alvarez-Gaitan, J.P.; Bilbao, J.I.; Corkish, R. A Review of Recycling Processes for Photovoltaic Modules. In Solar Panels and Photovoltaic Materials; InTechOpen: London, UK, 2018.

17. Pagnanelli, F.; Moscardini, E.; Altimari, P.; Padoan, F.C.S.M.; Abo Atia, T.; Beolchini, F.; Amato, A.; Toro, L. Solvent versus thermal treatment for glass recovery from end of life photovoltaic panels: Environmental and economic assessment. J. Environ. Manag. 2019, 248, 109313. [CrossRef] [PubMed]

18. Dias, P.; Veit, H. Recycling Crystalline Silicon Photovoltaic Modules. Emerg. Photovolt. Mater. 2018, 61-102. [CrossRef]

19. Veolia Group Veolia Opens the First European Plant Entirely Dedicated to Recycling Photovoltaic Panels. Available online: https://www.veolia.com/en/newsroom/news/recycling-photovoltaic-panelscircular-economy-france (accessed on 14 July 2020).

20. Nike*, S.r.l. II Trattamento dei Pannelli Fotovoltaici a Fine Vita. Available online: http://www.pvcycle.org/ wp-content/uploads/Nike_3rd-RC_2013.pdf (accessed on 14 July 2020).

21. CEN; CENELEC. WORK PROGRAMME 2016 European Standardization and Related Activities. Available online: https://www.cencenelec.eu/News/Publications/Publications/CEN-CENELEC-WP2016_EN. pdf (accessed on 21 July 2020).

22. Campadello, L.; Deubzer, O.; Langle, A.; Amadei, A.; Arienti, G.; Sala, M. Upgrading Regulations and Standards to Enable Recycling of CRM from WEEE. Available online: http://scrreen.eu/wp-content/ uploads/2019/06/SCRREEN-D8.2-Upgrading-regulations-and-standards-to-enable-recycling-of-CRMfrom-WEEE-V3.pdf (accessed on 21 July 2020).

23. Sasil, S.r.l. FRELP Project (LIFE+ 12-ENV/IT/000904). Available online: https://www.sasil-life.com/ricercae-sviluppo/progetti-life/progetto-frelp/ (accessed on 4 August 2020).

24. Geltz Umwelttechnologie GmbH ELSi-Recycling of Photovoltaic Modules. Available online: https: //geltz.de/en/elsi-pv/ (accessed on 4 August 2020).

25. DuPont ${ }^{\mathrm{TM}}$ Tedlar ${ }^{\circledR}$. Available online: https://www.dupont.com/brands/tedlar.html (accessed on 14 July 2020).

26. IEA-PVPS. End-of-Life Management of Photovoltaic Panels: Trends in PV Module Recycling Technologies. Available online: https://iea-pvps.org/wp-content/uploads/2020/01/End_of_Life_Management_of_ Photovoltaic_Panels_Trends_in_PV_Module_Recycling_Technologies_by_task_12.pdf (accessed on 21 July 2020).

27. Doi, T.; Tsuda, I.; Unagida, H.; Murata, A.; Sakuta, K.; Kurokawa, K. Experimental study on PV module recycling with organic solvent method. Sol. Energy Mater. Sol. Cells 2001, 67, 397-403. [CrossRef] 
28. Prado, P.F.A.; Tenório, J.A.S.; Espinosa, D.C.R. Alternative Method for Materials Separation from Crystalline Silicon Photovoltaic Modules. In Energy Technology 2017; Zhang, L., Drelich, J.W., Neelameggham, N.R., Guillen, D.P., Haque, N., Zhu, J., Sun, Z., Wang, T., Howarter, J.A., Tesfaye, F., et al., Eds.; Springer International Publishing: Cham, Switzerland, 2017; pp. 277-282.

29. Yan, Y.; Wang, Z.H.I.; Wang, D.; Cao, J.; Ma, W.; Wei, K.; Yun, L.E.I. Recovery of Silicon via Using KOH-Ethanol Solution by Separating Different Layers of End-of-Life PV Modules. JOM 2020, 72, 2624-2632. [CrossRef]

30. Granata, G.; Pagnanelli, F.; Moscardini, E.; Havlik, T.; Toro, L. Recycling of photovoltaic panels by physical operations. Sol. Energy Mater. Sol. Cells 2014, 123, 239-248. [CrossRef]

31. Pagnanelli, F.; Altimari, P.; Bellagamba, M.; Granata, G.; Moscardini, E.; Schiavi, P.G.; Toro, L. Pulsed electrodeposition of cobalt nanoparticles on copper: Influence of the operating parameters on size distribution and morphology. Electrochim. Acta 2015, 155, 228-235. [CrossRef]

32. Pagnanelli, F.; Moscardini, E.; Granata, G.; Atia, T.A.; Altimari, P.; Havlik, T.; Toro, L. Physical and chemical treatment of end of life panels: An integrated automatic approach viable for different photovoltaic technologies. Waste Manag. 2017, 59, 422-431. [CrossRef] [PubMed]

33. PhotoLife Project (LIFE13 ENV/IT/001033). Available online: http://www.photolifeproject.eu (accessed on 14 July 2020).

34. Pagnanelli, F.; Atia, T.A.; Altimari, P.; Baldassari, L.; Moscardini, E.; Padoan, F.C.; Toro, L. Pilot scale tests for recycling of photovoltaic panels by physical and chemical treatment. In Sustainable Industrial Processing Summit SIPS 2017 Volume 7. Recycling, Secondary Batteries and Environmental Protection; FLOGEN Star Outreach: Montreal, QC, Canada, 2017; pp. 114-120.

35. Sathaiyan, N.; Nandakumar, V.; Ramachandran, P. Hydrometallurgical recovery of silver from waste silver oxide button cells. J. Power Sources 2006, 161, 1463-1468. [CrossRef]

36. Woods, D.R. Appendix D: Capital Cost Guidelines. In Rules of Thumb in Engineering Practice; Wiley-VCH Verlag GmbH \& Co. KGaA: Weinheim, Germany, 2007; pp. 376-436.

37. Garrett, D.E. Appendix 1: Equipment Cost Estimates. In Chemical Engineering Economics; Butterworth-Heinemann: London, UK, 1983; pp. 636-637.

38. Uçar, S.; Ozkan, A.R.; Yanik, J.; Karagöz, S. The influence of the waste ethylene vinyl acetate copolymer on the thermal degradation of the waste polypropylene. Fuel Process. Technol. 2008, 89, 1201-1206. [CrossRef]

Publisher's Note: MDPI stays neutral with regard to jurisdictional claims in published maps and institutional affiliations.

(C) 2020 by the authors. Licensee MDPI, Basel, Switzerland. This article is an open access article distributed under the terms and conditions of the Creative Commons Attribution (CC BY) license (http://creativecommons.org/licenses/by/4.0/). 